\title{
UTILIZATION OF LOKPANTA OIL SHALE IN PORTLAND CEMENT MANUFACTURING IN NIGERIA: A THERMODYNAMIC APPROACH
}

\author{
O. A. EHINOLA*, QINSHAN ZHU \\ Multiphase Reaction Laboratory, Institute of Process Engineering \\ CAS, P.O. Box 353, Beijing, 100080, P.R. China
}

\begin{abstract}
A thermodynamic model is applied to calculate the amount of oil shale ash (OSA), which could be used as raw material in the manufacturing of ordinary Portland cement (OPC). XRF, XRD and SEM analyses of the materials were carried out, and the thermodynamic properties for pure materials in the $\mathrm{CaO}-\mathrm{SiO}_{2}$ system are obtained from literature, database of FACTSAGE and STGE. The main minerals and liquid phase present after blending OSA with cement raw material (employing different blending ratios) at different temperatures indicate that 15 to $20 \%$ of OSA would be suitable as clinker material. Temperatures of 1300 and $1400{ }^{\circ} \mathrm{C}$ can be used for such a blending ratio due to relatively high amount of $C_{3} S$ and $C_{2} S$. The XRD and SEM of the blend at $1350{ }^{\circ} \mathrm{C}$ further show that $C_{3} S$ and $C_{2} S$ are the dominant species present. Addition of OSA will definitely lower the clinkering temperature by 50 to $100{ }^{\circ} \mathrm{C}$. Thermomechanical analysis for the suggested blend ratio shows that the liquid is formed at temperatures higher than $1150{ }^{\circ} \mathrm{C}$.
\end{abstract}

\section{Introduction}

Oil shales are rocks that yield oil upon pyrolysis and are considered one of the largest fossil energy potential in the world. An oil shale deposit has been discovered in the Lokpanta area of Abakaliki Fold Belt of the Benue Trough in 1990, and it was named Lokpanta oil shale deposit [1]. Previous studies on the oil shale include: thermal and geochemical characterization of Lokpanta oil shale [2], economic evaluation, recovery techniques and environmental implications of oil shale [3], hydrocarbon potential and depositional environment of oil shale $[4,5]$.

There is little or no awareness as to the use of oil shale in Nigeria because of the early discovery of crude oil in the Niger Delta Basin. However, oil shale can be utilized in manufacturing of Portland cement, as chemical feed-

*Corresponding author: e-mail ehinola01@yahoo.com 
stock, brick, and as asphalt fillers in road construction as well as fossil fuel. In addition to the utilization of spent oil shale after combustion, it can also be used to reduce the temperature required for clinkering reactions.

The principal constituents of ordinary Portland cement (OPC) are calcium silicates $\left(\mathrm{Ca}_{3} \mathrm{SiO}_{5}\right.$ and $\left.\mathrm{Ca}_{2} \mathrm{SiO}_{4}\right)$, aluminate $\left(\mathrm{Ca}_{3} \mathrm{Al}_{2} \mathrm{O}_{6}\right)$, ferrite $\left(\mathrm{Ca}_{4}\left(\mathrm{Al}_{\mathrm{x}} \mathrm{Fe}_{1-\mathrm{x}}\right)_{4} \mathrm{O}_{10}\right.$ and they are designated as $\mathrm{C}_{3} \mathrm{~S}, \mathrm{C}_{2} \mathrm{~S}, \mathrm{C}_{3} \mathrm{~A}$, and $\mathrm{C}_{4} \mathrm{AF}$ [6]. Other minerals such as gypsum, anhydrite, calcite, calcium and magnesium oxides, $\mathrm{Na}$ and $\mathrm{K}$ sulphates are usually also present [6].

Thermodynamic models allow easy and fast parameter variations and make it possible to predict the composition of mineral assemblages under different conditions. The experimental determination of phase diagrams is a time-consuming and costly task and becomes even more pronounced as the number of components increases [7]. The calculation of phase diagrams reduces the effort required to determine equilibrium conditions in a multicomponent system. A preliminary phase diagram can be obtained from extrapolation of the thermodynamic functions of constituent subsystems. This preliminary diagram can be used to identify composition and temperature regimes where maximum information can be obtained with minimum experimental effort. This information can then be used to refine the original thermodynamic functions [6].

A thermodynamic cement model has been developed and applied to utilization of oil shale in cement clinkers and to envisage if it can provide the energy source for the clinkering reactions in Jordan [7]. Generally, high percentage of ash in oil shale has been the greatest treat to its usability as fuel. The recent call for alternative source of energy and ban on the importation of cement as well as the policy of government on self-sufficient in cement production in Nigeria have prompted us to examine oil shale as a raw material in the cement industry.

In this study, a comprehensive thermodynamic modeling was conducted to understand the reactions and phases that exist when utilizing the oil shale in production of cement clinker. The results of theoretical thermodynamic equilibrium calculations are compared with experimental values for verifications of these calculations. It is to envisage that the result of this research will therefore create the desired awareness for various stakeholders and policy makers to vibrant ways of engaging and empowering the local cement industry for sustainable development.

\section{Geological setting of Lokpanta oil shale}

A northeast-southwest trending belt of Cretaceous sedimentary rocks underlies the study area (Fig. 1). The detailed geology and information on the raw oil shale are already published [2-5]. The Eze-Aku Formation which is the focus of this study consists of black calcareous shales, shelly limestones, siltstones and sandstones that overstep the Asu River Group in most parts of 


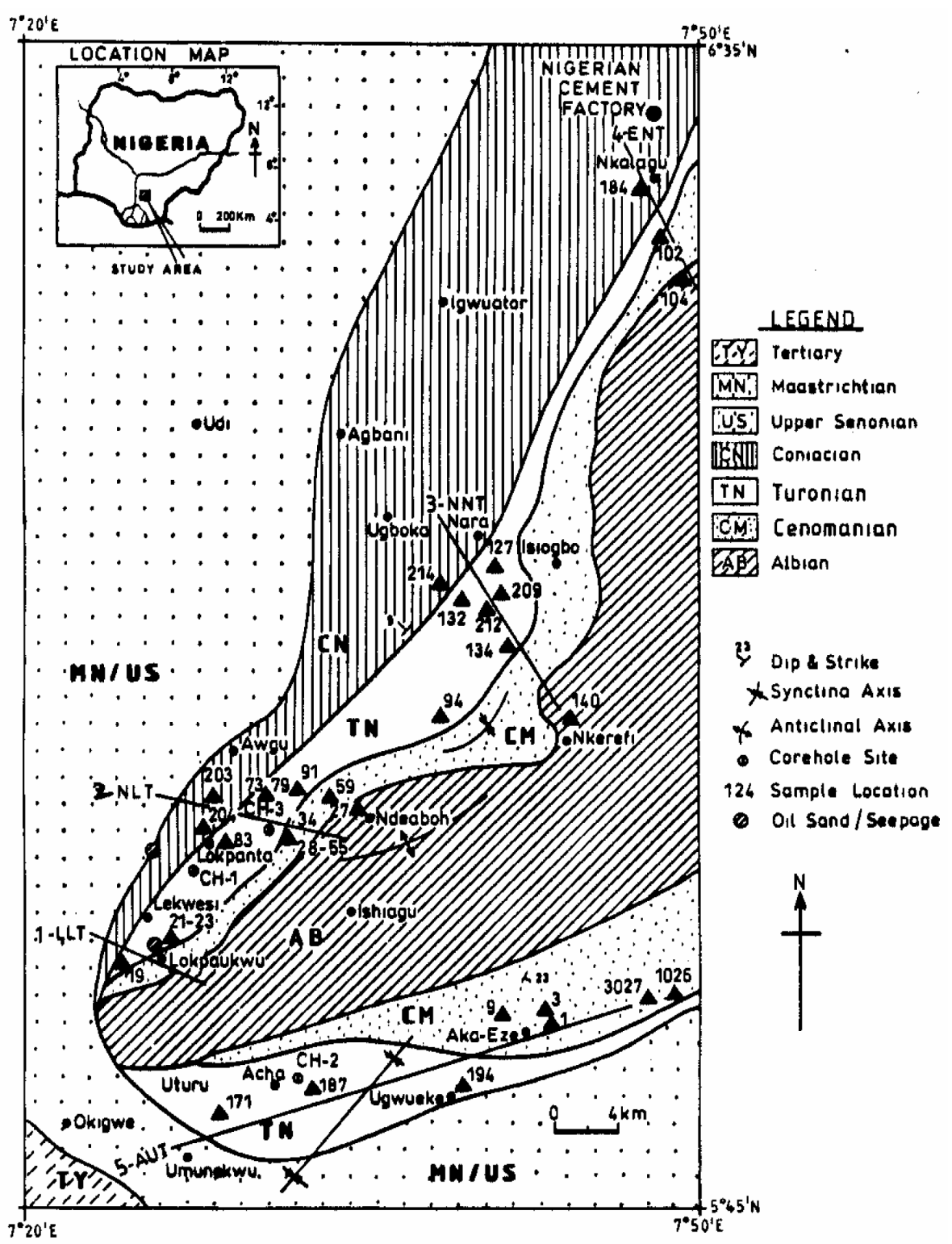

Fig. 1. Geological map ot the lower Benue Trough, SE Nigeria (Modified after Ehinola, 2002).

the Benue Trough [3-5, 8-11]. The Eze-Aku Formation represents the second depositional cycle and has been dated late Cenomania - early Turonian $[2,4,5,8,12]$. 


\section{Materials and methods}

The sample materials for this study are oil shale ash (OSA) from Lokpanta and Acha towns, limestones from Nkalagu quarry, clay (kaolinite), and cement raw materials (from Dangote, and Benue cement companies). The materials were crushed to $<150 \mu \mathrm{m}$ while the oil shale was ashed in a SRJX413 muffle furnace at different temperatures. $50 \mathrm{~g}$ of the oil shale sample was heated in air to $500{ }^{\circ} \mathrm{C}$ in 30 minutes (at approximately $9{ }^{\circ} \mathrm{C}$ per minute), 500 to $815^{\circ} \mathrm{C}$ in 60 minutes (at approximately $5^{\circ} \mathrm{C}$ per minute and kept at $815{ }^{\circ} \mathrm{C}$ for 3 hours (at approximately of $5{ }^{\circ} \mathrm{C}$ per minute) and allow to cool at normal temperature [7]. The particle size distribution of sample materials used for this study is presented in Fig. 2. The crystalline component of each material was carried out using automated X'Pert Pro PAnalytical X-ray diffraction (XRD) model. Each sample was put into the sample holder, with two slits of $1 / 2$ and $1^{\circ}$ selected for the incident beam path and $5.0 \mathrm{~mm}$ slit for the diffractive path. The compositions of the oil shale ash (OSA), cement raw material, limestones, and clay are presented in Table 1, while the crystalline components are indicated in Fig. 3 and summarized in Table 2. The combination of XRF and XRD results was used to provide an approximate analysis of the main component present in the ash (e.g. anhydrite, quartz, kaolinite, magnetite, lime). Samples of cement raw material from Dangote and Benue cement companies were blended with oil shale ash at different temperatures. Samples of Nkalagu limestone and clay (kaolinite) were also used (Table 3). The scanning electron microscope (SEM) analysis on different materials was carried out using JEOL JSM6700F model field emission scanning electron microscope. This confirms that the main components present in OSA, limestone and clay are kaolinite, calcite and quartz (Figures $4 \mathrm{a}-\mathrm{c}$ ).

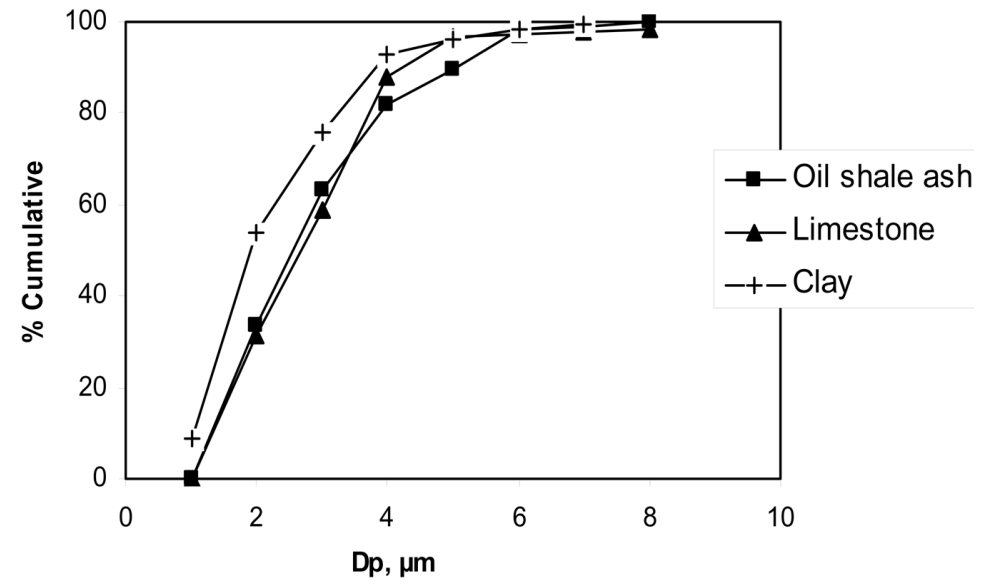

Fig. 2. Particle size distribution of oil shale ash, limestone and clay used for this study. 


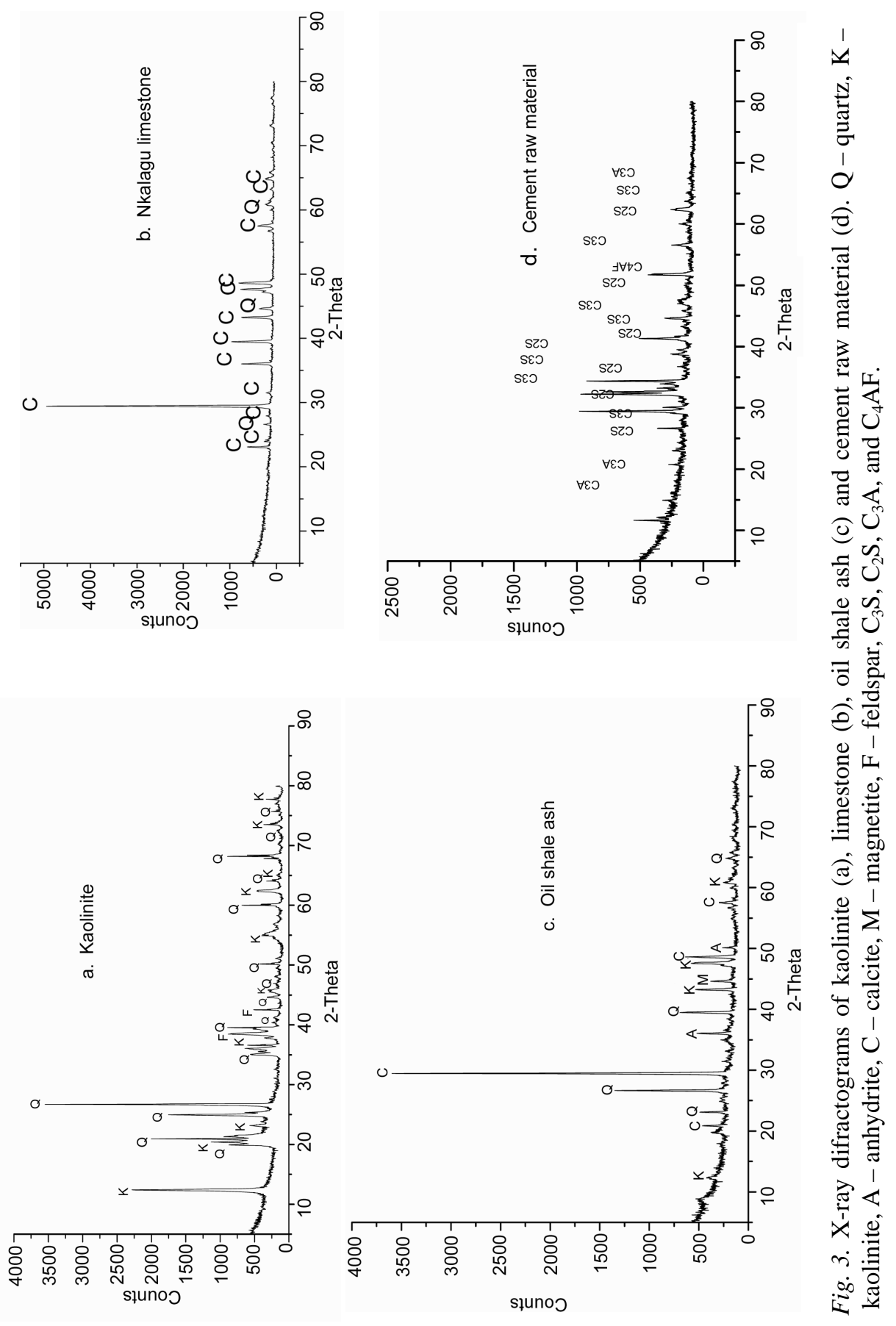



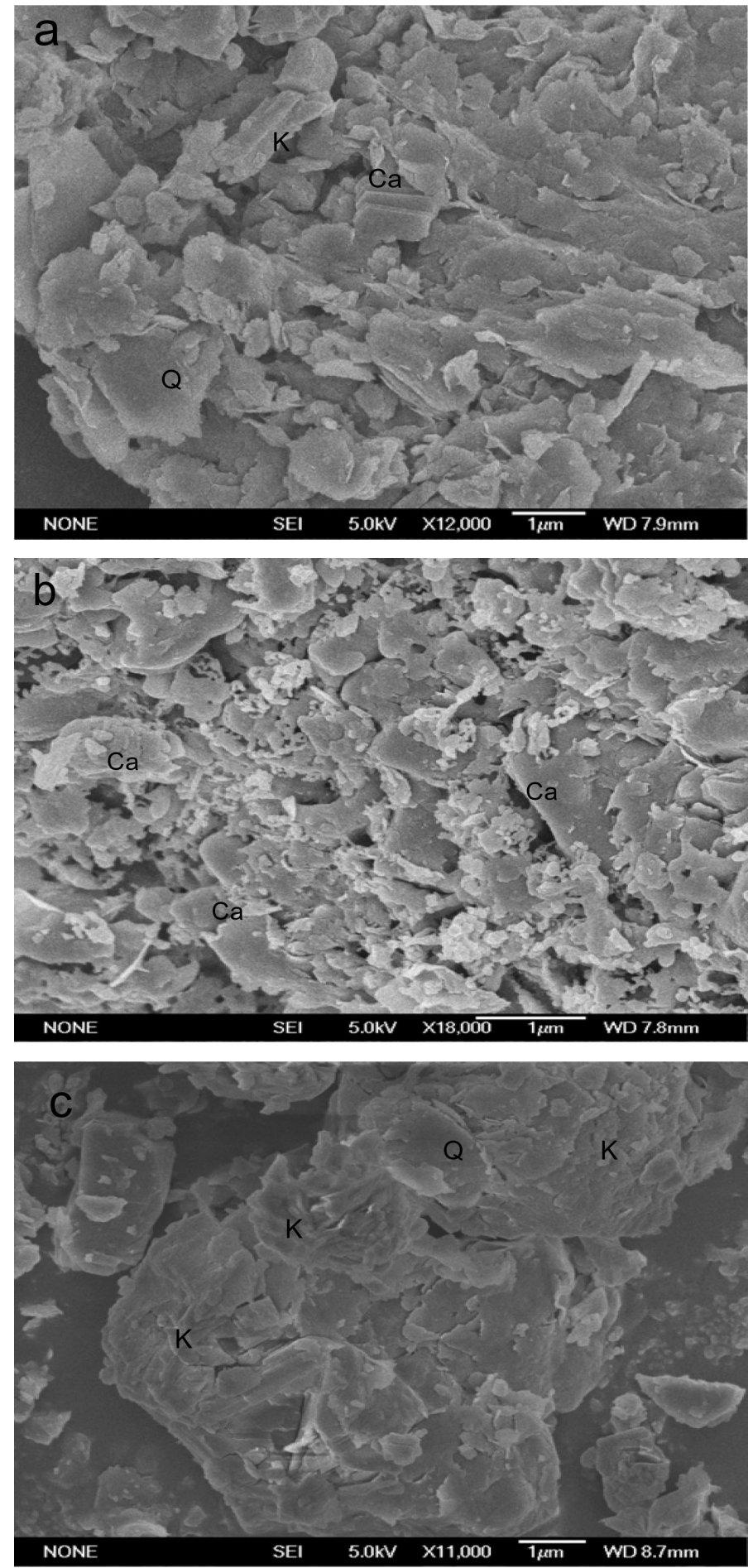

Fig. 4. Scanning electron photomicrograph of oil shale ash (OSA) (a), limestone (b), clay (c). $\mathrm{Ca}$ - calcite, $\mathrm{Q}$ - quartz, $\mathrm{K}$ - kaolinite. 
Table 1. Chemical compositions of limestone, clay, oil shale ash (OSA), and cement raw material (XRF analysis)

\begin{tabular}{|l|c|c|c|c|}
\hline \multirow{2}{*}{ Oxide } & \multicolumn{4}{|c}{ Percentage by weight } \\
\cline { 2 - 5 } & Limestone & Clay & Oil shale ash & Cement raw material \\
\hline $\mathrm{SiO}_{2}$ & 7.48 & 60.65 & 46.86 & 19.89 \\
$\mathrm{CaO}$ & 48.29 & 0.61 & 19.34 & 61.38 \\
$\mathrm{Fe}_{2} \mathrm{O}_{3}$ & 1.12 & 0.64 & 3.21 & 2.98 \\
$\mathrm{Al}_{2} \mathrm{O}_{3}$ & 2.61 & 25.73 & 10.03 & 6.03 \\
$\mathrm{MgO}$ & 0.77 & 0.09 & 0.91 & 1.78 \\
$\mathrm{MnO}$ & 0.02 & 0.01 & 0.03 & 0.15 \\
$\mathrm{Na}_{2} \mathrm{O}$ & 0.04 & 0.03 & 0.07 & 0.11 \\
$\mathrm{~K}_{2} \mathrm{O}$ & 0.20 & 0.03 & 1.11 & 0.88 \\
$\mathrm{P}_{2} \mathrm{O}_{5}$ & 0.10 & 0.03 & 0.37 & 0.22 \\
$\mathrm{TiO}_{2}$ & 0.12 & 2.49 & 0.72 & 0.33 \\
$\mathrm{LOI}_{\text {Total }}$ & 38.62 & 9.54 & 15.74 & 4.73 \\
\hline
\end{tabular}

Table 2. Crystalline components of limestone, clay, and oil shale ash material (XRD analysis)

\begin{tabular}{|l|c|c|c|}
\hline Minerals & Limestone & Clay & Oil shale ash \\
\hline Quartz & 8.64 & 62.06 & 35.15 \\
Calcite & 91.36 & - & 35.15 \\
Kaolinite & - & 37.94 & 18.63 \\
Anhydrite & - & - & 9.65 \\
Magnetite & - & - & 3.08 \\
\hline
\end{tabular}

Table 3. Composition of blends at 1100, 1200, 1300, 1350 and $1450{ }^{\circ} \mathrm{C}$

\begin{tabular}{|l|c|c|c|}
\hline Blend No. & Limestone & Clay & Oil Shale Ash \\
\hline OSA-1 & 60 & 10 & 25 \\
OSA-2 & 55 & 25 & 20 \\
OSA-3 & 55 & 20 & 25 \\
OSA-3 & 50 & 20 & 30 \\
OSA-4 & 50 & 15 & 35 \\
OSA-5 & 50 & 10 & 40 \\
\hline
\end{tabular}

\section{Thermodynamic calculations}

Thermodynamics calculations were performed using a computer program $(\mathrm{C}++)$, and mathematical models which are normally used for predictions of multiphase equilibra, liquidus temperatures, and proportions of liquid, and solid phases in a certain atmosphere. The thermodynamic data used for this study are obtained from literature [7, 13-22], phase diagrams, database of sources such as FACTSAGE, H.S.C, CHEMSAGE, THERMOCAL and STGE, as well as experimental data. Gibbs energy functions of all phases of the system and especially the excess Gibbs energy coefficients of the solu- 
tion phases are necessary to calculate a temperature-composition phase diagram. The $\mathrm{CaO}-\mathrm{SiO}_{2}$ system has been of great importance in the manufacturing of cement because $\mathrm{CaO}$ and $\mathrm{SiO}_{2}$ are the major components. The thermodynamic properties of pure materials in the $\mathrm{CaO}-\mathrm{SiO}_{2}$ system are summarized in Table 4. A number of different mathematical approaches have been previously used to produce a reasonably calculated phase diagram. In this study, the stoichiometric compound, solid solution of end members and the liquid phases as well as formation energy of mixing were modeled.

The temperature dependence of the Gibbs energies of stoichiometric compound phases is described as polynomial in Eq. (1),

$$
G=a+b T+c T \ln T+d T^{2}+e T^{-1}+f T^{3},
$$

where $G$ is the standard Gibbs energy, $T$ is absolute temperature, and $a, b, c$, $d, e$ and $f$ are constants whose values need to be determined from experimental data. The Gibbs energy is then obtained from the GibbsHelmholtz equation

$$
G_{T}=H_{T}-T S_{T},
$$

where $H_{T}$ and $S_{T}$ are calculated using equations on Table 4.

The end-member (terminal) solid solutions $\left(\mathrm{CaO}\right.$ and $\left.\mathrm{SiO}_{2}\right)$ are modeled using the

$$
\begin{gathered}
G_{s s}=G_{r e f}+G_{\text {ideal }}+G_{e x s} . \\
G_{r e f}=X_{C a O} G_{C a O}+X_{S i O 2} G_{S i O 2} \\
G_{i d e a l}=R T\left(X_{\mathrm{CaO}} \ln X_{\mathrm{CaO}}+X_{\mathrm{SiO}_{2}} \ln X_{\mathrm{SiO} 2}\right) \\
G_{e x s}=X_{\mathrm{CaO}} X_{\mathrm{SiO} 2} \sum L_{\mathrm{CaO}, \mathrm{SiO} 2}\left(X_{\mathrm{CaO} \mathrm{O}}-X_{\mathrm{SiO} 2}\right)^{i}
\end{gathered}
$$

$G_{e x s}$ is the excess Gibbs energy, and expressed by the Redlich-Kister polynomial $[14,18]$, where $L$ is the binary interaction parameter that has been optimized by several workers $[14,18,19]$. The temperature dependence of $L$ may be expressed as

$$
L=a_{i}+b_{i} T,
$$

where $a_{i}$ and $b_{i}$ are considered as enthalpy and entropy terms respectively.

The mole fractions can be obtained from Eq. (8):

$$
X_{\mathrm{CaO}}=\frac{n_{\mathrm{CaO}}}{n_{\mathrm{CaO}}+n_{\mathrm{SiO} 2}} ; \quad X_{\mathrm{SiO} 2}=\frac{n_{\mathrm{SiO} 2}}{n_{\mathrm{CaO}}+n_{\mathrm{SiO} 2}},
$$

where $X_{\mathrm{CaO}}$ and $X_{\mathrm{SiO} 2}$ are the mole fractions, while $n_{\mathrm{CaO}}$ and $n_{\mathrm{SiO} 2}$ are number of moles of $\mathrm{CaO}$ and $\mathrm{SiO}_{2}$, respectively [21]. 


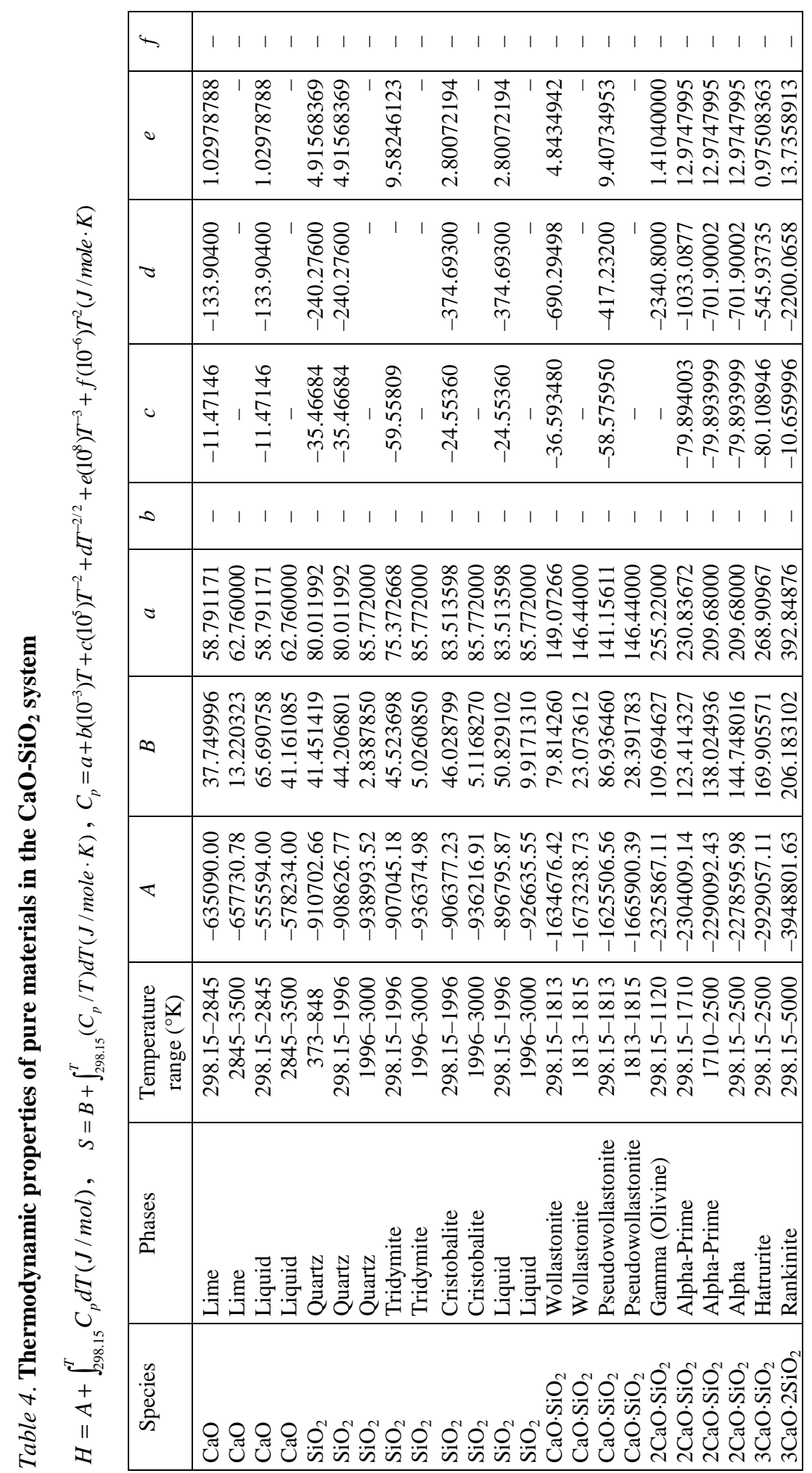


The association model was used to describe the Gibbs energy of the liquid phase [14]. The association-species solution model uses intermediate "Chemical species" with their corresponding thermodynamic data, to represent the negative, non-ideal mixing of the end-member components in a system. For example, a liquid $\mathrm{CaSiO}_{3}$ (1) species is ideally mixed with endmember $\mathrm{CaO}$ (l) and $\mathrm{SiO}_{2}$ (l) to represent the liquid phase in the $\mathrm{CaO}-\mathrm{SiO}_{2}$ binary system. While $\mathrm{CaSiO}_{3}$ (1) may not exist as a chemical entity that can be isolated and characterized, this species in the model can accurately represent the negative interaction energy that occurs between calcium and silica in oxide liquid solution [14].

The associate species for the modeling of the liquid phase include $\mathrm{CaSiO}_{3}$ (wollastonite) which is stable between 298 to $1398 \mathrm{~K}, \mathrm{CaSiO}_{3}$ (pseudowollastonite) which is stable at 1398 to $1817 \mathrm{~K}, \mathrm{Ca}_{2} \mathrm{SiO}_{4}$ (calcium othosilicate), $\mathrm{Ca}_{3} \mathrm{SiO}_{5}$ which is stable in the temperature range from 1523 to $2343 \mathrm{~K}$ and $\mathrm{Ca}_{3} \mathrm{Si}_{2} \mathrm{O}_{7}$ (rankinite) which is stable up to $1737 \mathrm{~K}$ [17]. Based on Besmann and Spear [14] equation:

$$
G_{e x s}=X_{S i O 2}\left(1-X_{S i O 2}\right)\left[(141000-65 T)+(-10000-10 T)\left(1-2 X_{S i O 2}\right)\right] \text {. }
$$

Chemical reactions and associated equilibrium constants can be used in determining the relative amounts of each species [14].

$$
\mathrm{CaO}_{(l)}+\mathrm{SiO}_{2(l)}=\mathrm{CaSiO}_{3(l)} \mathrm{Keq}=\left(\gamma_{\mathrm{CaSiO} 3(l)}\right) / \gamma_{\mathrm{CaO}} \gamma_{\mathrm{SiO} 2(l)} .
$$

However, the Gibbs energy of formation of the main species were calculated using

$$
G_{f}=G_{p}-G_{r 1}-G_{r 2},
$$

where $G_{f}$ is standard Gibbs energy of formation, $G_{p}$ is the product and $G_{r l}$ and $G_{r 2}$ are reactants.

$\mathrm{C}++$ computer program language was adopted for the above mathematical models to calculate the quantities of minerals that are noted to be the most important constituents in Portland cement such as tricalcium silicate $\left(\mathrm{C}_{3} \mathrm{~S}\right)$, calcium othosilicate $\left(\mathrm{C}_{2} \mathrm{~S}\right)$, tricalcium aluminate $\left(\mathrm{C}_{3} \mathrm{~A}\right)$ and tetracalcium aluminoferate $\left(\mathrm{C}_{4} \mathrm{AF}\right)$ at different temperatures.

\section{Thermomechanic analysis}

Thermomechanic analysis was carried out using a $50 \mathrm{mg}$ sample of oil shale ash compressed to $0.35 \mathrm{MPa}$. The ash pellet was sintered in an oven to $1450{ }^{\circ} \mathrm{C}$ and sintering occurred at $1050^{\circ} \mathrm{C}$. This was used to verify the results obtained from the computer program calculations. Scanning electron microscopic (SEM) images were obtained for the suggested blend at appropriate temperature. 


\section{Results and discussion}

The thermodynamic properties for a pure $\mathrm{CaO}-\mathrm{SiO}_{2}$ system which includes $\mathrm{CaO}, \mathrm{Al}_{2} \mathrm{O}_{3}, \mathrm{SiO}_{2}$ and intermediate compounds such as $\mathrm{CaSiO}_{3}, \mathrm{Ca}_{2} \mathrm{SiO}_{4}$, $\mathrm{Ca}_{3} \mathrm{SiO}_{5}, \mathrm{Ca}_{3} \mathrm{Si}_{2} \mathrm{O}_{7}$, and $\mathrm{Ca}_{3} \mathrm{Al}_{2} \mathrm{O}_{6}$ are presented in Table 4. The free energy $(G)$, enthalpy of mixing $(H)$, entropy $(S)$ and heat capacity $(C p)$ are calculated using Table 4 equations, and a typical result of calculated thermodynamic functions for the $\mathrm{CaO}-\mathrm{SiO}_{2}$ system at different temperatures is shown in Table 5. The results coincide excellently with those of the database of Viewdata of Factsage 5.1 [22]. Computation of crystalline, solid solution and liquid phases were performed using equations (1) to (11). Figure 5 shows the results of thermodynamic calculations for oil shale ash (OSA), $\mathrm{C}_{3} \mathrm{~S}_{2}$ occurring in large proportions. $\mathrm{C}_{3} \mathrm{~S}$ and $\mathrm{C}_{2} \mathrm{~S}$ which are important constituents of Portland cement are formed below $1300{ }^{\circ} \mathrm{C}$. The low quantity of lime in OSA would possibly affect its cementing properties, as it is noted that the amount of lime to form $\mathrm{CaO}$ should be from 65 to $75 \%$ (Fig. 6). $\mathrm{C}_{2} \mathrm{~S}$ starts to precipitate out of the liquid slag above $1450{ }^{\circ} \mathrm{C}$, and this is slightly different from the data reported for the Jordanian oil shale [7]. This may be attributed to the mineral composition of the Lokpanta oil shale.

Table 5. A typical result of calculated thermodynamic functions for the $\mathrm{CaO}-\mathrm{SiO}_{2}$ system

\begin{tabular}{|c|c|c|c|c|}
\hline \multicolumn{5}{|c|}{$\mathrm{CaO} \cdot S i O_{2}$ (wollastonite) } \\
\hline$T(\mathrm{~K})$ & $C_{p}(\mathrm{~J} / \mathrm{mol} \cdot \mathrm{K})$ & $H(\mathrm{~J} / \mathrm{mol})$ & $S(\mathrm{~J} / \mathrm{mol} \cdot \mathrm{K})$ & $G^{0}$ \\
\hline 298.15 & 86.204312 & -1634676.420000 & 79.814260 & -1658473.041619 \\
498.15 & 107.316273 & -1613213.165438 & 134.900188 & -1680413.694091 \\
698.15 & 116.863081 & -1587931.187490 & 179.245724 & -1713071.589919 \\
898.15 & 122.171315 & -1561373.631277 & 214.537501 & -1754060.488168 \\
1098.15 & 125.573248 & -1534217.821997 & 243.534840 & -1801655.607024 \\
1298.15 & 127.963617 & -1506712.802529 & 268.061376 & -1854696.677910 \\
1498.15 & 129.751966 & -1478974.060548 & 289.284482 & -1912365.607024 \\
1698.15 & 131.151368 & -1451064.505497 & 307.978030 & -1974057.397118 \\
1813.00 & 146.440000 & -1451404.096000 & 287.418533 & -1972493.895522 \\
\hline \multicolumn{5}{|c|}{$2 \mathrm{CaO} \cdot \mathrm{SiO}(\mathrm{alpha})$} \\
\hline$T(\mathrm{~K})$ & $C_{p}(\mathrm{~J} / \mathrm{mol} \cdot \mathrm{K})$ & $H(\mathrm{~J} / \mathrm{mol})$ & $S(\mathrm{~J} / \mathrm{mol} \cdot \mathrm{K})$ & \\
\hline 298.15 & 128.108993 & -2278595.980000 & 144.748016 & -2321752.600970 \\
498.15 & 156.532353 & -2247289.509460 & 225.096780 & -2359421.470572 \\
698.15 & 170.537014 & -2210381.174272 & 289.847263 & -2412738.040687 \\
898.15 & 178.145946 & -2171708.412521 & 341.196743 & -2478154.267576 \\
1098.15 & 182.853775 & -2132312.960125 & 383.150118 & -2553069.262143 \\
1298.15 & 186.051088 & -2092544.892408 & 418.447536 & -2635752.561335 \\
1498.15 & 188.372078 & -2052549.486054 & 448.853936 & -2725000.009954 \\
1698.15 & 190.141584 & -2012397.762519 & 475.536947 & -2819930.828574 \\
1898.15 & 191.541736 & -1972129.202454 & 499.299104 & -2919873.795962 \\
2098.15 & 192.682156 & -1931768.099806 & 520.712245 & -3024300.496708 \\
2298.15 & 193.632664 & -1891330.651621 & 540.196845 & -3132784.029908 \\
2498.15 & 194.439828 & -1850828.358366 & 558.070513 & -3244972.209224 \\
\hline
\end{tabular}




\begin{tabular}{|c|c|c|c|c|}
\hline \multicolumn{5}{|c|}{$3 \mathrm{CaO} \cdot \mathrm{SiO}_{2}$ (hatrurite) } \\
\hline$T(\mathrm{~K})$ & $C_{p}(\mathrm{~J} / \mathrm{mol} \cdot \mathrm{K})$ & $H(\mathrm{~J} / \mathrm{mol})$ & $S(\mathrm{~J} / \mathrm{mol} \cdot \mathrm{K})$ & $G^{0}$ \\
\hline 298.15 & 150.853422 & -2929057.110000 & 169.905571 & -2979714.455994 \\
498.15 & 212.956083 & -2886465.893485 & 279.216891 & -3025557.787708 \\
698.15 & 232.098880 & -2836217.557910 & 367.383947 & -3092706.660638 \\
898.15 & 240.896833 & -2784519.010382 & 435.552235 & -3175710.250266 \\
1098.15 & 245.865911 & -2732364.381225 & 490.461983 & -3270965.207774 \\
1298.15 & 249.048185 & -2680008.925000 & 536.280042 & -3376180.860887 \\
1498.15 & 251.264730 & -2627539.434037 & 575.544732 & -3489791.774479 \\
1698.15 & 252.903467 & -2574992.256128 & 609.881223 & -3610662.055712 \\
1898.15 & 254.169752 & -2522385.506982 & 640.383514 & -3737929.474394 \\
2098.15 & 255.181912 & -2469729.668497 & 667.820235 & -3870916.694458 \\
2298.15 & 256.012756 & -2417031.597885 & 692.750954 & -4009077.202887 \\
2498.15 & 256.709493 & -2364296.225386 & 715.595256 & -4151960.514538 \\
\hline \multicolumn{5}{|c|}{$3 \mathrm{CaO} \cdot 2 \mathrm{SiO} 2(\mathrm{rankinite})$} \\
\hline$T(\mathrm{~K})$ & $C_{p}(\mathrm{~J} / \mathrm{mol} \cdot \mathrm{K})$ & $H(\mathrm{~J} / \mathrm{mol})$ & $S(\mathrm{~J} / \mathrm{mol} \cdot \mathrm{K})$ & \\
\hline 298.15 & 305.269112 & -3948801.630000 & 206.183102 & -4010275.121861 \\
498.15 & 301.092166 & -3888583.196748 & 360.735072 & -4068283.372942 \\
698.15 & 311.433486 & -3824228.235579 & 471.162317 & -4153170.207287 \\
898.15 & 320.012146 & -3756794.342669 & 559.073416 & -4258926.131175 \\
1098.15 & 326.611689 & -3687512.279124 & 632.014689 & -4381559.209545 \\
1298.15 & 331.781770 & -3617019.860256 & 694.266845 & -4518282.364534 \\
1498.15 & 335.941793 & -3545671.477946 & 748.524032 & -4667072.756053 \\
1698.15 & 339.371104 & -3473682.084017 & 796.586329 & -4826405.158308 \\
1898.15 & 342.256179 & -3401191.743607 & 839.712395 & -4995091.825540 \\
2098.15 & 344.724790 & -3328297.007989 & 878.815134 & -5172182.981468 \\
2298.15 & 346.867087 & -3255067.456144 & 914.576925 & -5356902.415656 \\
2498.15 & 348.748447 & -3181555.046645 & 947.520822 & -5548604.187942 \\
2698.15 & 350.417462 & -3107799.721279 & 978.056377 & -5746742.533838 \\
2898.15 & 351.911039 & -3033832.929471 & 1006.510154 & -5950850.331484 \\
\hline
\end{tabular}

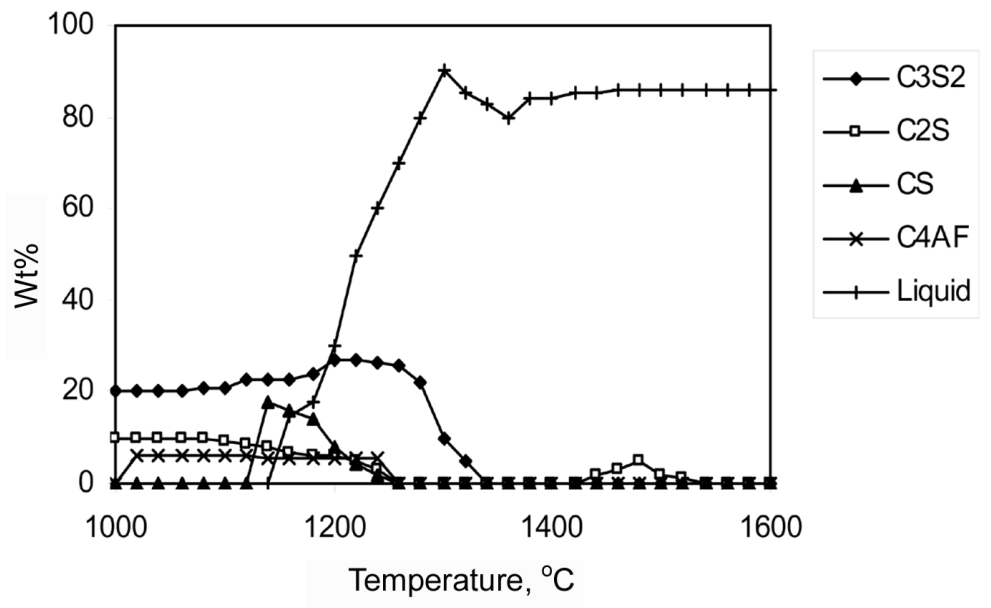

Fig. 5. Thermodynamic equilibrium diagram for oil shale ash (OSA). 


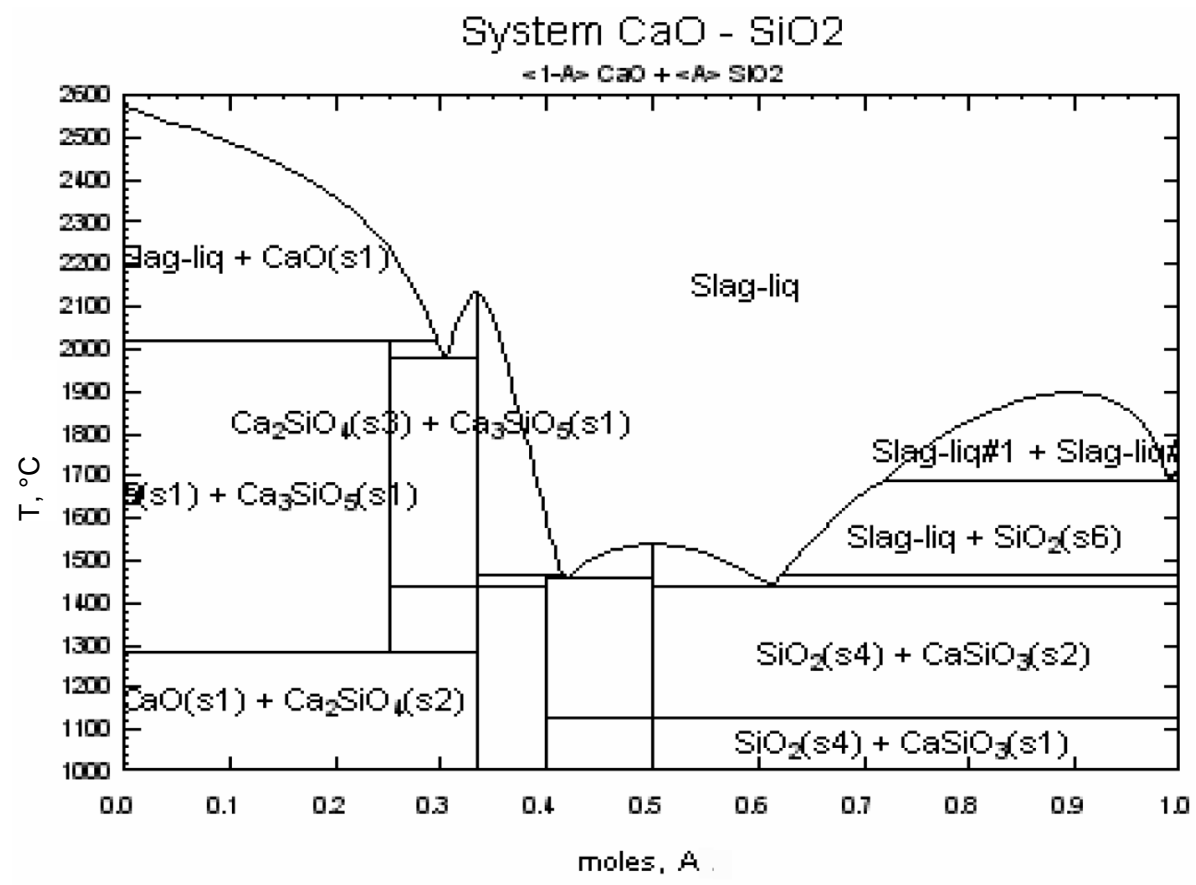

Fig. 6. Phase diagram of the $\mathrm{CaO}-\mathrm{SiO}_{2}$ system $[17,22]$.

Main clinker minerals and liquid phase present after blending OSA with cement raw material at $1250,1300,1350,1450{ }^{\circ} \mathrm{C}$ were computed and the results plotted as shown in Fig. 7. The results of the thermodynamic modelling (e.g. Fig. 7) show that even at the lowest level of OSA addition (15\%), the clinker minerals are very significantly altered. At $1250{ }^{\circ} \mathrm{C}$, neither the OSA blends nor the cement raw material would be a suitable clinker material due to low amount of $\mathrm{C}_{3} \mathrm{~S}$ which is reported to be stable at temperatures between 1300 and $1800{ }^{\circ} \mathrm{C} . \mathrm{C}_{3} \mathrm{~S}$ and $\mathrm{C}_{2} \mathrm{~S}$ are noted to be in equilibrium at above 1250 and below $1420{ }^{\circ} \mathrm{C}$ [7]. The OSA blending ratio of 15 to $20 \%$ could be used in making clinker materials at temperatures between 1300 and $1350{ }^{\circ} \mathrm{C}$ due to relatively high amounts of $\mathrm{C}_{3} \mathrm{~S}$ and $\mathrm{C}_{2} \mathrm{~S}$. At this blending ratio, there are enough liquids $(>20 \%)$ to proceed to clinkering reactions during the process of making cement. The minimum amount of liquid required for clinkering reactions is about $20 \%$ [7].

Table 3 shows the different blending ratios employed in the mathematical computation of the raw materials which are considered in the manufacturing of cement. The optimum blending ratio obtained for the constituents that is close to Portland cement is $20 \%$ OSA, $15 \%$ clay and $65 \%$ limestone (Fig. 8). The constituents present at different ratios indicate that a temperature between 1300 and $1400^{\circ} \mathrm{C}$ can be used for the blending ratio that makes up all necessary components of cement clinkers (Fig. 9). This is an indication that the addition of OSA will reduce the required temperature to about 


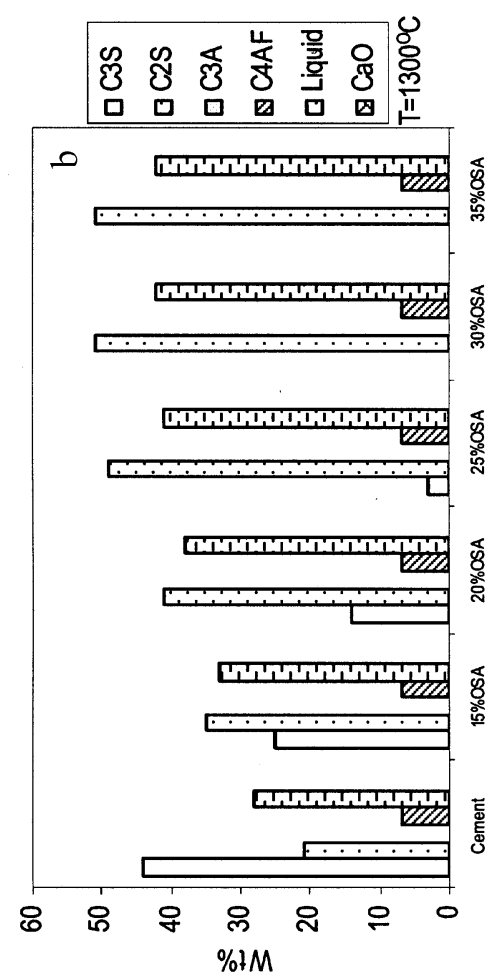

๗ู

กิ
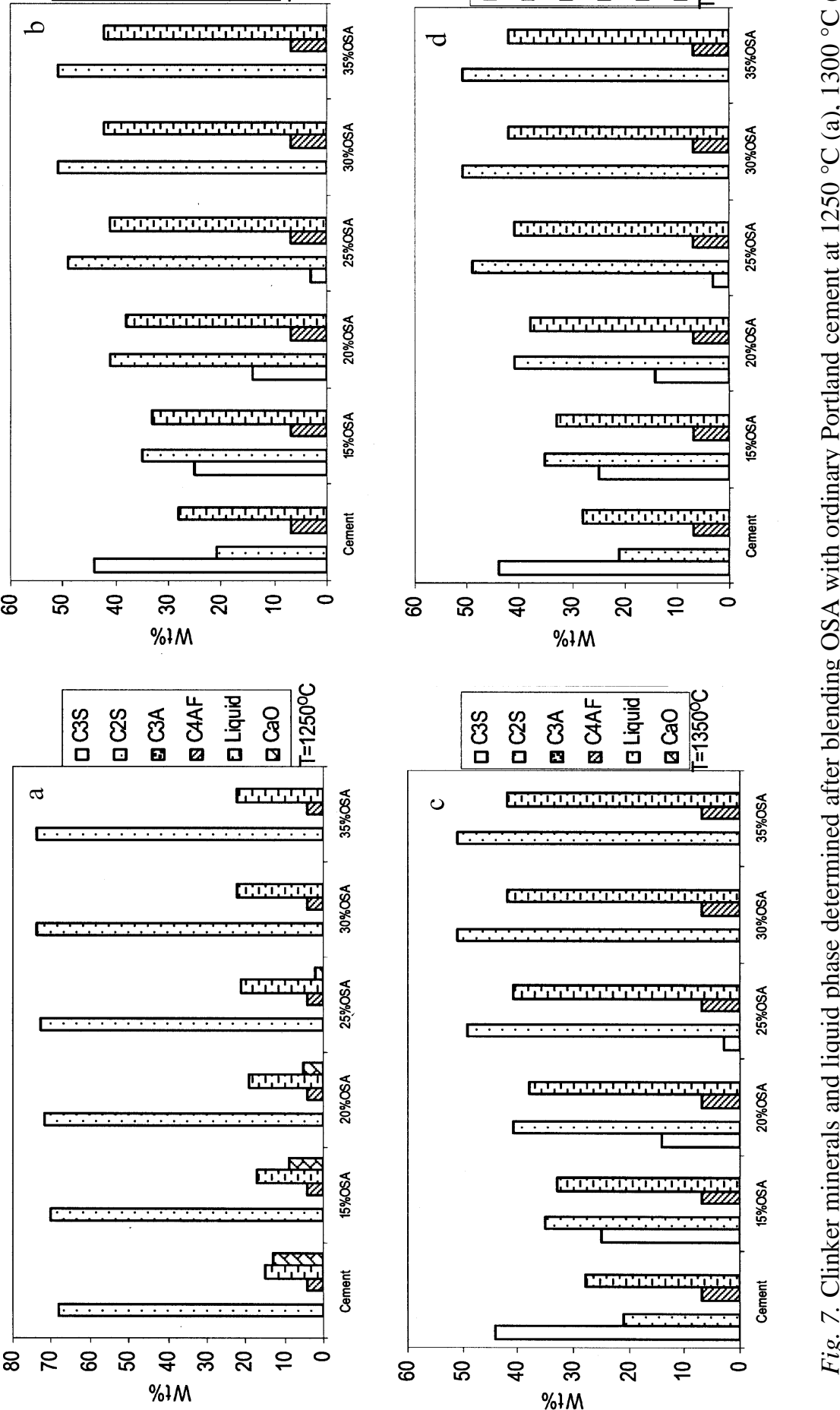

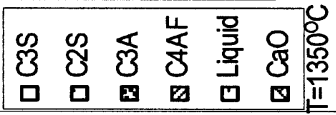
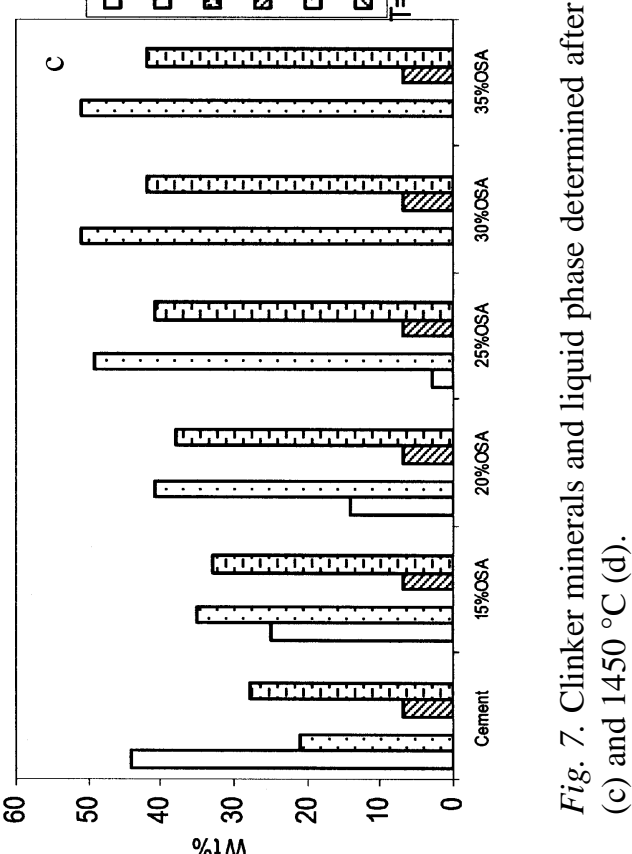


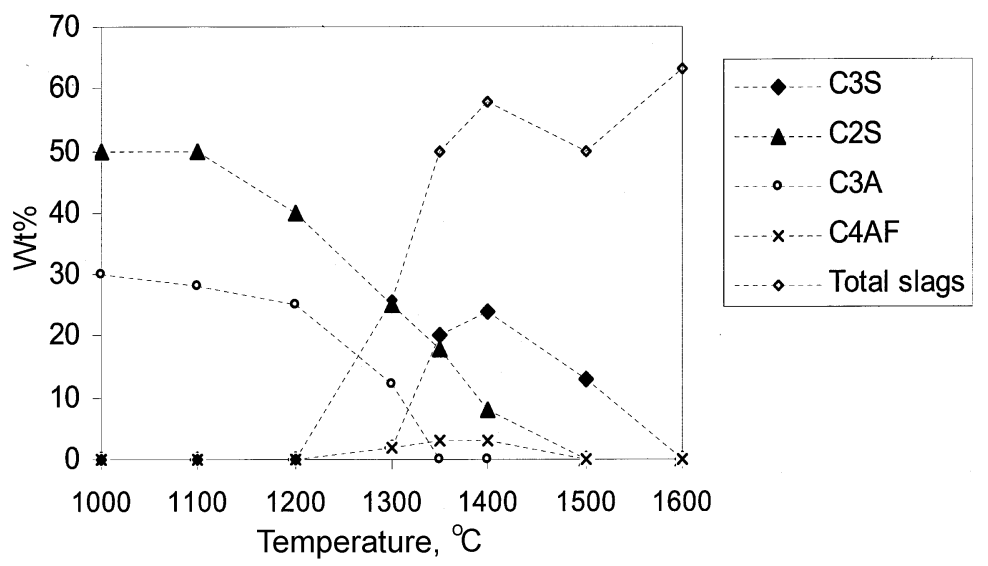

Fig. 8. Calculation for the main constituents present when blending $25 \%$ OSA, $15 \%$ clay and $60 \%$ lime.

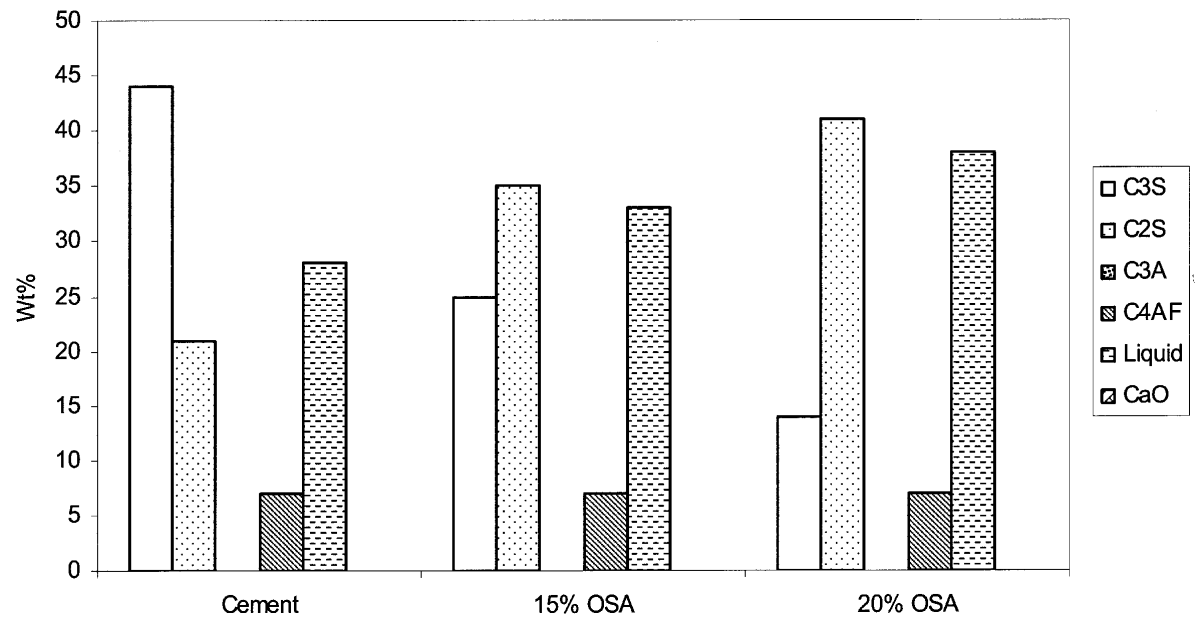

Fig. 9. Percentage of cement components present when blending $20 \%$ OSA, $15 \%$ clay and $65 \%$ limestone.

$1350-1400{ }^{\circ} \mathrm{C}$ instead of $1450-1500{ }^{\circ} \mathrm{C}$. At this temperature, there will be enough liquid constituents to undergo the clinkering reactions [7].

Thermomechanical analysis result for the suggested blend ratio shows that the liquid has formed at temperatures higher than $1150{ }^{\circ} \mathrm{C}$. Sintering occurred at this temperature when OSA was not blended, and that resulted in the shrinkage of the pellet. The XRD and SEM of the blend at $1350{ }^{\circ} \mathrm{C}$ show that $\mathrm{C}_{3} \mathrm{~S}$ and $\mathrm{C}_{2} \mathrm{~S}$ are the dominant components present (Fig. 10). 

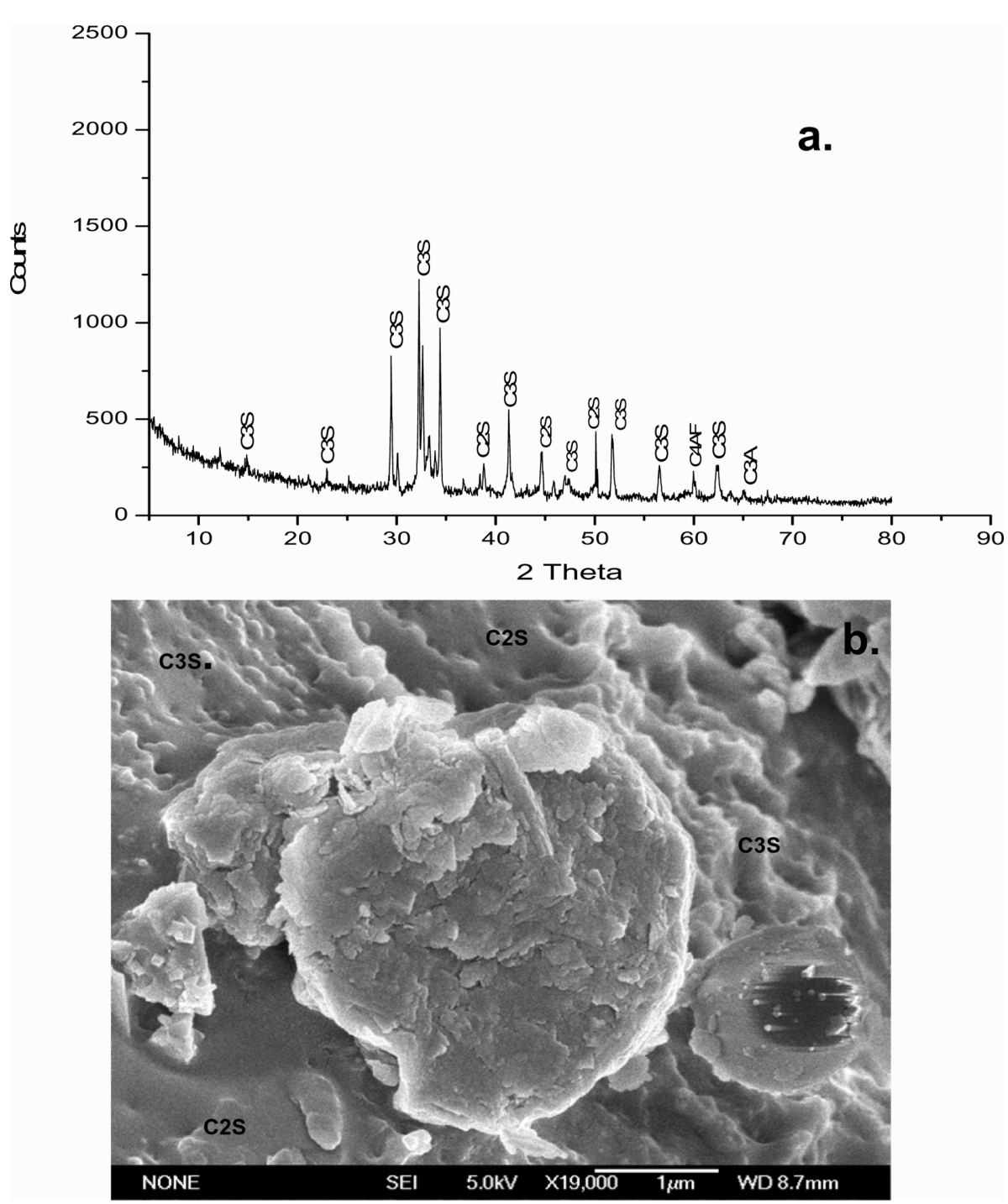

Fig. 10. XRD of the suggested blend ratio (a) and SEM of the suggested blend ratio at temperature $>1350{ }^{\circ} \mathrm{C}(\mathrm{b})$.

\section{Conclusions}

Huge amounts of oil shale ash (OSA) and the cost of its disposal have been the greatest challenge to usability of oil shale as a source of energy. An attempt has been made on utilization of Lokpanta oil shale as raw material in the cement manufacturing in Nigeria using a thermodynamic model. From the different blending ratios employed in the thermodynamic calculation, the optimum ratio obtained for the constituents that is close to Portland cement was $20 \%$ OSA, $15 \%$ clay and $65 \%$ of limestone. Temperature between 1300 
and $1400{ }^{\circ} \mathrm{C}$ is suggested for the blending ratio that makes up all necessary components of cement clinkers indicating a reduction in the required clinkering temperature. More experiments should be carried out on the suggested blending ratio to ascertain the geotechnical engineering properties and applications.

\section{Acknowledgements}

This work has been supported by the Chinese Academy of Sciences and the Academy of Sciences for the Developing World [formerly Third World Academy of Sciences] through their CAS-TWAS Postdoctoral fellowship2005. Most of the calculations were performed at the Institute of Process Engineering, CAS Beijing China. The authors thank Drs. Zhang, Zhxie, and Huang of IPE, and also Mr Adetunmbi Adebayo, and Li Wei of the Institute of Computer Technology, Beijing for their assistance during the computer programming.

\section{REFERENCES}

1. Ekweozor, C. M., Unomah, G. I. First discovery of oil shale in the Benue Trough, Nigeria // Fuel. 1990. Vol. 69, No. 4. P. 502-508.

2. Sonibare, O. O., Ehinola, O. A., Egashira, E. Thermal and geochemical characterization of Lokpanta oil shale, Nigeria // Energy Convers. Manage. 2005. Vol. 46, No. 15-16. P. 2335-2344

3. Ehinola, O. A., Sonibare, O. O., Akanbi, O. A. Economic evaluation, recovery techniques, and environmental implications of the oil shale deposits in the Abakaliki anticlinorium, Southeastern Nigeria// Oil Shale. 2005. Vol. 22, No. 1. P. 5-19

4. Ehinola, $O$. A. Depositional Environment and Hydrocarbon Potential of the Oil Shale Deposit from the Abakaliki Fold Belt, Southeastern Nigeria, Ph.D thesis, University of Ibadan, 2002, $240 \mathrm{p}$.

5. Ehinola, O. A., Bassey, C. E., Ekweozor, C. M. Preliminary studies of the lithostratigraphy and depositional environment of the oil shale deposits of Abakaliki anticlinorium, southeastern, Nigeria // Journal of Mining and Geology. 2003. Vol. 39, No. 2. P. 85-94.

6. Lobthenbach, B., Winnefeld, F. Thermodynamic modeling of the hydration of Portland cement // Cement Concr. Res. 2006. Vol. 36, No. 2. P. 209-226.

7. Al-Otoom, A. Y. A thermodynamic study on the utilization of Jordanian oil shale in the cement industry // Oil Shale. 2005. Vol. 22, No. 1. P. 37-49.

8. Ojoh, K. A. Cretaceous geodynamic evolution of the southern part of of the Benue trough (Nigeria) in the equatorial domain of the South Atlantic. Stratigraphy, basin analysis and paleo-oceanography// Bulletin des Centres de Recharches Exploration-Production Elf-Aquitaine. 1990. Vol. 14, No. 2. P. 419-442. 
9. Reyment, $R$. A. Aspects of the Geology of Nigeria. - Ibadan, Nigeria: Ibadan Univ. Press, 1965. 145 p.

10. Benkhelil, J. The origin and evolution of the Cretaceous Benue trough (Nigeria) // J. Afric. Earth Sci. 1989. Vol. 8, No. 2-4. P. 251-282.

11. Akande, S. O., Erdtmann, B. D. Burial metamorphism (thermal maturation) in Cretaceous sediments of the southern Benue Trough and Anambra basin, Nigeria // Am. Assoc. Petrol. Geol. Bull. 1998. Vol. 82, No. 6. P. 1191-1206.

12. Amajor, L. C. The Cenomanian hiatus in the Southern Benue Trough, Nigeria // Geological Magazine. 1985. Vol. 122, No. 1. P. 39-50.

13. Eriksson, G., Wu, P., Pelton, A. D. Critical evaluation and optimization of the thermodynamic properties and phase diagrams of the $\mathrm{MgO}-\mathrm{Al}_{2} \mathrm{O}_{3}, \mathrm{MnO}-\mathrm{Al}_{2} \mathrm{O}_{3}$, $\mathrm{FeO}-\mathrm{Al}_{2} \mathrm{O}_{3}, \mathrm{Na}_{2} \mathrm{O}-\mathrm{Al}_{2} \mathrm{O}_{3}$ and $\mathrm{K}_{2} \mathrm{O}-\mathrm{Al}_{2} \mathrm{O}_{3} / /$ Calphad. 1993. Vol. 17, No. 2. P. 189-205.

14. Besmann, T. M., Spear, K. E. Thermodynamical modeling of oxide glasses // J. Am. Ceram. Soc. 2002. Vol. 85, No. 12. P. 2887-2894.

15. Pelton, A. D., Wu, P. Thermodynamic modeling in glass-forming melts // J. Non-Cryst., Solids. 1999, Vol. 253, No. 1. P. 178-191.

16. Eriksson, G., Hack, K. SGTE Pure Substance Database, 1996 Version, produced by the Scientific Group Thermodata Europe, and obtained through GTT Technologies. - Germany: Herzogonrah, 1996.

17. Lee, Y. E. Thermodynamics of $\mathrm{CaO}-\mathrm{SiO}_{2}$ system// Calphad. 1982. Vol. 6, No. 4. P. 283-291.

18. Chatterjee, N. D. Applied Mineralogical Thermodynamics: Selected Topics. Springer-Verlag, 1991. P. 33-164.

19. Bale, C. W., Eriksson, G. Metallurgical thermodynamical databases: A review // Canad. Metall. Quarterly. 1990. Vol. 29, No. 2. P. 105-132.

20. Saunders, N., Miodownik, A. P. Calphad (Calculation of Phase Diagrams), A Comprehensive Guide: Pergamon Materials series. - Elsevier Science Ltd, 1998. P. 30-408.

21. Smith, B. E. Basic Chemical Thermodynamics, fifth edition. - London: Imperial College Press, 2004. P. 104-240.

22. Jak, E., Degterov, S. A., Pelton, A. D., Happ, J., Hayes, P.C. Thermodynamic modeling of the system $\mathrm{Al}_{2} \mathrm{O}_{3}-\mathrm{SiO}_{2}-\mathrm{CaO}-\mathrm{FeO}-\mathrm{Fe}_{2} \mathrm{O}_{3}$ to characterise coal ash slags // Impact of Mineral Impurities in Solid Fuel Combustion / R. P. Gupta, T. F. Wall, L. Baxter (Eds.). NY: Kluwer Academic Plenum Publ., 1999. P. 723-733.

Presented by J. Hilger

Received December 27, 2007 